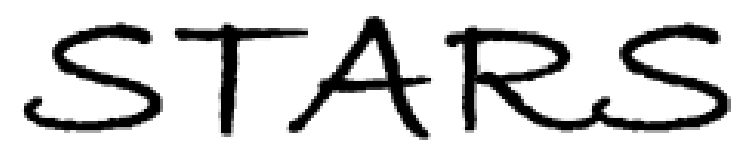

University of Central Florida

STARS

$1-1-2011$

\title{
Social Implications from Agricultural Taskscapes In The Southwestern Amazon
}

John H. Walker

University of Central Florida

Find similar works at: https://stars.library.ucf.edu/facultybib2010 University of Central Florida Libraries http://library.ucf.edu

This Article is brought to you for free and open access by the Faculty Bibliography at STARS. It has been accepted for inclusion in Faculty Bibliography 2010 s by an authorized administrator of STARS. For more information, please contact STARS@ucf.edu.

\section{Recommended Citation}

Walker, John H., "Social Implications from Agricultural Taskscapes In The Southwestern Amazon" (2011). Faculty Bibliography 2010s. 2056.

https://stars.library.ucf.edu/facultybib2010/2056

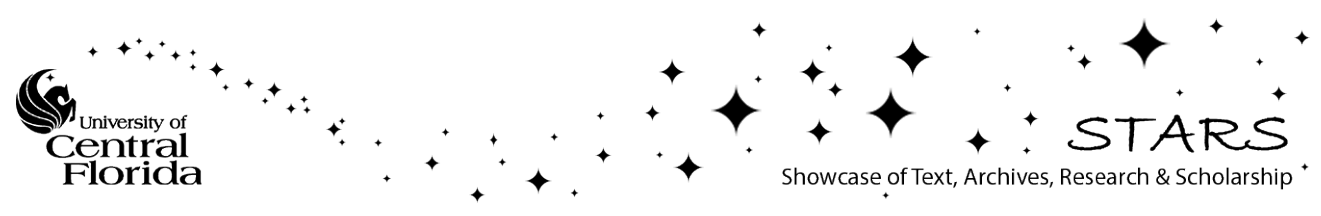




\title{
SOCIAL IMPLICATIONS FROM AGRICULTURAL TASKSCAPES IN THE SOUTHWESTERN AMAZON
}

\author{
John H. Walker
}

\begin{abstract}
Across the Americas, but particularly in the Amazon Basin, precolumbian farmers invested their labor in features such as canals, causeways, and raised fields, creating agricultural landscapes. These landscapes required organized action in order to build and maintain them. Such actions can be usefully described as "tasks" to draw specific connections between communal work and landscape features (Ingold 1993). Using two parallel examples from the precolumbian Bolivian Amazon, this article presents landscape features as correlates of the variety and scale of tasks that compose the processes of creating and managing them. Data come from remote sensing and pedestrian survey. The execution of some tasks affects the execution of others, meaning that landscapes are the result of overlapping, interdependent communal tasks. This taskscape perspective allows landscapes to be compared with greater precision and shows that details of local spatial and task organization are important to understanding agricultural change. The comparison of two taskscapes reveals details of daily life and intensive agriculture that are obscured by the classification of societies as states or chiefdoms.
\end{abstract}

A través de las Américas, pero particularmente en la cuenca Amazónica, los agricultores precolombinos invirtieron su trabajo en rasgos como canales, terraplenes y campos elevados, creando paisajes agricolas. Estos paisajes requirieron de acciones organizadas para su construcción y mantenimiento. Estas acciones pueden ser descritas útilmente como "tareas" para rastrear conexiones especificas entre tareas comunales y rasgos del paisaje (Ingold 1993). Usando dos ejemplos paralelos de la Amazonia Boliviana precolombina, este artículo presenta rasgos del paisaje como indicadores de la variedad y escala de las tareas que comprenden los procesos de crearlos y manejarlos. Los datos relacionados al paisaje provienen de la teledetección y de un trabajo de reconocimiento pedestre. La ejecución de algunas tareas afecta la realización de otras, lo que significa que los paisajes son el resultado de tareas comunales interdependientes que se sobreponen. Esta perspectiva de las tareas para producir paisajes (taskscape) permite comparar los paisajes con más precisión y muestra que los detalles de la organización local, espacial y de las tareas son esenciales para entender el cambio agrícola. La comparación de dos "taskscapes" revela detalles de la vida cotidiana y de la agricultura intensiva que son oscurecidos por la clasificación de las sociedades como estados o cacicazgos.

A well-tested recipe in American archaeology is to start at a regional scale and interpret settlement patterns using models of political or economic organization. These powerful models draw on universal theories from outside archaeology: central place theory, optimal foraging theory, or definition of a site hierarchy (Anschuetz et al. 2001). Most approaches define "sites," and having located them, analyze sites and their patterns through time and across space (Dunnell 1992; Kowalewski 2008). This kind of spatial pattern is a main ingredient in the definition of evolutionary categories such as state and chiefdom, and spatial patterns have been defined in the Viru Val- ley, the Mississippi Valley, the Valley of Mexico, and around the world.

Archaeological evidence of intensive agriculture is not recovered (or sought) as often as evidence of settlement, and spatial patterns of intensive agriculture that match expectations of evolutionary interpretations of intensive agriculture have proven more elusive. Beginning in the 1930s, the connection between intensive agriculture and sociopolitical organization has been an influential problem, although Steward had always emphasized how some irrigation infrastructure was not agricultural (Lawton et al. 1976; Steward 1930, 1933). Wittfogel posited a strong connection between irrigation

John H. Walker University of Central Florida, Department of Anthropology, 4000 Central Florida Boulevard, Howard Phillips Hall 309, Orlando, FL 32816-1361 (john.walker@ucf.edu) 
agriculture and political power (Wittfogel 1957). By the 1960s and 1970s, connections between irrigation and society were pursued by ethnographers and archaeologists (Downing and Gibson 1974). Continuing research has problematized the link between the state as an evolutionary category and agricultural infrastructure, because irrigation is organized before the state can be detected (Dillehay et al. 2005; Wilkinson 2003), because modern irrigators solve agricultural problems without the state (Fernea 1970), and because modern states destroy irrigation systems through their mismanagement (Scott 1998). It may be that when decisions about the management of intensive agriculture (and common-pool resources in general) are disconnected from knowledge of how agriculture works, systems quickly become unsustainable (Ostrom 1990, 2005).

Critics of evolutionary approaches to sociopolitical organization suggest that they can obscure diversity in the archaeological record and divert attention to an abstract category at the expense of historical detail (Pauketat 2007; Smith 2003; Yoffee 2005). A more fruitful approach may be to characterize sociopolitical organization not by comparison to universal models, but by constructing models of organization from archaeological evidence in particular regions, thereby studying the political landscape (Smith 2003). These redefinitions of political relationships in the archaeological record are part of larger trends in archaeological interpretation that are more explicitly historical. Especially in analyses of intensive agriculture, evolutionary models maintain their influence because archaeological evidence of intensive agriculture is scarce, but also because the archaeology of small settlements and agricultural infrastructure has often been understudied, particularly in comparison with richly furnished tombs, monumental architecture, and large sites. Interpreting the relationship between intensive agriculture and political power begins with archaeological evidence of intensive agriculture.

\section{Landscapes and Taskscapes}

Agriculture can change in many ways: through intensification, when labor, fertilizer, or other inputs are added; through extension, in which an agricultural system spreads; and through abandonment, when infrastructure goes out of use. To study agricultural change, analysis begins with local histories of agricultural work, not the impact of political control from outside the system. This approach to landscape first defines specific landscape features, many of which are seldom incorporated into standard definitions of "site," and then builds analytical units from those features (Anschuetz et al. 2001; Erickson 2006a). In the Near East, for example, terraces, threshing floors, and irrigation channels are atoms of a historical ecology of landscapes incorporating more than six millennia of human experience (Wilkinson 2003). This article is predicated on a definition of landscape that balances environment and culture: "landscape is the material manifestation of the relation between humans and the environment" (Crumley 1987, 1994). When seen in diachronic perspective, landscapes become palimpsests and the records of many kinds of human activity, as they are continually written, erased, and rewritten.

This definition of landscape grows from the tradition of geography created at Berkeley and led by Carl Sauer, who strongly influenced American geography and South American anthropology (Denevan 1966, 2001; Erickson 2008; Lathrap 1970, 1977; Sauer 1925; Steward 1946). "Morphological" geography defined landscape as the basic unit of geography, and argued for an understanding that blended both the natural and the cultural. Opposed by a geographical tradition that defines regions as mental constructs, Olwig argues that landscape should continue in this tradition of cultural geography (Olwig 1996). In this sense, landscape maintains the connection between land and legal identity: rights and obligations. Developing this perspective, Ingold argues that there is no basis by which to distinguish between the natural and the cultural in landscape or taskscape (Ingold 1993). Ingold recognizes difficulties in reconstructing past activities from present landscapes, but takes the practice of moving through the landscape, or dwelling, as a key aspect of archaeological and anthropological fieldwork.

This analysis concerns cultural landscapes, according to Sauer's classification, and focuses on only two aspects of the landscape: differences in elevation and the control of water and fire, although these factors also influence the movement of plants and animals. When comparing landscapes, one can- 
not be "more cultural" than another, even if there are important differences between the two of them and the people who made and maintained them. It is useful to think of the two landscapes linked to particular customs and laws about the relationships between people and the land, however, as in the sense of landscape redefined by Olwig. This article is framed by historical ecology insofar as it uses archaeological data to write the history of particular agricultural landscapes.

These agricultural landscapes were valuable to their inhabitants, and because they grow and develop, they can be theorized as landesque capital (or innovations that create enduring fixed capital in the land beyond a single crop or cropping cycle; see Blaikie and Brookfield 1987; Brookfield 2001:55) and recognized as "places" (Ashmore 2002). Archaeological studies of agricultural change in general and intensification in particular show that they are a diverse and complex historical process (Stone 1991, 1993, 1994, 1996; Stone and Downum 1999). In a comparative, South American case, by the late 1990 s the interpretation of raised field agriculture in the Lake Titicaca basin revolved around two positions. First, that landscapes of intensive agriculture in many cases predated centralized administration and were organized without the assistance (or hindrance) of centralized administration (Erickson 2006a). Second, although conceding such local organization is possible, Janusek and Kolata argue that the Tiwanaku state had an important role in the creation and maintenance of raised field agriculture (Janusek and Kolata 2004). Examining agricultural landscape over the long term suggests that this dichotomy between "top-down" and "bottom-up" control may be overdrawn (Erickson 1999; Kolata 1986; Kolata and Ortloff 1996; Kolata et al. 2000). Spatial analysis of agriculture can identify and define patterns of landscape features, but how can these patterns then be linked to social structures or units? They cannot be linked directly because of the palimpsest nature of landscape and the ability of local institutions to build and maintain landscape features. The greatest obstacle to interpretation of spatial patterns is that the same pattern (a block of raised fields, for example) could be interpreted as the correlate of an autonomous group of local farmers, or as the correlate of an administrative division within a centralized polity. This problem of equi- finality means that defining clear spatial units is insufficient, and the analogy must be more specific. Instead of drawing analogies to levels of organization or all-embracing social units, spatial patterns are connected to specific tasks that required or facilitated communal labor. Such a specific analysis shifts the focus to a smaller scale, and more specific analogies (Stahl 1993; Wylie 1992).

Ingold's idea of the "taskscape" links landscape features to groups of people and their communal tasks. Of landscape features and their associated tasks, some tasks affect the execution of others and some are more isolated. This difference means that landscapes differ in terms of how many tasks are associated with their constituent features, and how those tasks fit together in both space and time. This interlocking quality defines a taskscape (Ingold 1993). A taskscape is connected to a landscape as speech is connected to thought: they are inseparable, although one exists as material objects at particular points in space, and one exists as actions (or tasks) at particular points in time. Taskscapes can be characterized and compared through their material correlates in the landscape. A more complex taskscape consists of more tasks of distinct types, requiring the coordination of more people and more groups of people. A taskscape is defined here as complex insofar as it is made up of tasks with different requirements (places, people, plants, animals, tools) that overlap in time and space. They allow us to draw connections between each landscape feature and the tasks associated with its creation and use. Such tasks make up the "normal business of life" (Ingold 1993: 154). Connections between taskscape and landscape can be seen at different scales, because many tasks modify the material landscape, and some modifications of the landscape permit or hinder other tasks. Through landscape features, it is possible to study specific intersections of daily practice and environment. Landscape features and their patterns are interpreted at smaller scales, as specific analogies are described and evaluated. By setting aside classification of the entire landscape according to universal models of political centralization and instead connecting tasks with landscape features, a taskscape perspective provides a basis for more detailed understanding of the differences between different examples of local social organization. Regardless of what other kinds of sociopolitical organization may be related to these 
landscapes, these conflicting sets of agricultural tasks were coordinated, and this process is reflected at local scales. Although a large number of patterns can potentially be discerned in an agricultural landscape (much as an effectively infinite number of alignments can be derived from the Nazca lines or Stonehenge), not all of them were meaningful to their builders and first users. Those patterns with stronger analogues are of greater interest and are presumably close to indigenous ideas about landscape.

The durability of these landscapes (and taskscapes) over many centuries allows archaeological study and analysis today. Across South America, landscapes stretch across long distances and are rich palimpsests built during many different periods. After decades during which few archaeologists worked in the Amazon Basin, recent years have seen the development of many new research projects. Previous work on Marajó Island has been published in detail, including the results of comprehensive remote sensing survey (Bevan and Roosevelt 2003), and Schaan's research on the Camutins chiefdom shows how Amazonians managed landscapes, in this case for fishing rather than agriculture (Schaan 2004). The Central Amazon Project has outlined the extent and chronology of occupation along the Madeira and Amazon rivers, downstream from the Llanos de Mojos (Neves 2008). In the Xingu to the east, Heckenberger and his colleagues have documented a complex of large towns and connecting causeways that they argue to be urban in scale (Heckenberger et al. 2008). To the north and west, in Brazil's Acre state, geoglyphs taking the form of ring ditches and other geometric shapes are revealed by deforestation and studied using Google Earth (Schaan et al. 2007). Within this arc of managed landscapes in the southwest Amazon, what makes the Llanos de Mojos (or Mojos) distinctive is that agricultural infrastructure is visible in the savanna. In Mojos itself, Prümers has excavated large mounds near Trinidad, to the south, and argued for the presence of stratification, based on artifacts associated with some burials (Prümers 2000, 2001, 2002; see also Lombardo and Prümers 2010). Erickson's recent work has focused on artificial fisheries and ring ditches in eastern Mojos (Erickson 2000, 2008; Erickson and Balée 2006). The recent Handbook of South American Archaeology contains several chapters that summarize developments in lowland archae- ology (Drennan 2008; Oyuela-Caycedo 2008; Politis 2008; Versteeg 2008). These and previous summaries of Amazonian archaeology show that the range of topics and geographic areas that are now under investigation is growing rapidly (McEwan et al. 2001).

Much of this research documents various managed landscapes across South America. The raised fields associated with Araucanian society are particularly interesting, in that they are associated with the societies that most effectively resisted incorporation into the Inca, Colonial and Chilean states (Dillehay 2007; Dillehay et al. 2007). Many types of earthworks and settlement remains in tropical settings around the world are more easily detected from the air than on the ground. As remote sensing resources become both more sophisticated and more available, it is likely that other areas of precolumbian earthworks will become known.

When the landscape is described in terms of discrete units, or landscape features, these can be linked to the particular tasks required to create and maintain them, and the tasks they afforded. This article defines specific landscape features in the material record, and assembles them into larger units or patterns, connecting those patterns to the lived experience of the people who created, maintained, and used them. Landscape features are defined and measured using formal characteristics: length, width, height, and shape. After features have been described, patterns in their arrangement can be defined. Specific features and types of features are then linked to specific tasks. Finally, larger patterns and the types of such patterns are linked to different kinds of tasks. For this purpose, a pattern described from spatial analysis has explanatory value in direct proportion to the associated tasks it affords.

Tasks affect and are affected by the spatial patterns of agricultural infrastructure. This can be demonstrated in the comparison of two related agricultural landscapes. Two archaeological examples of agricultural infrastructure from similar cultural, environmental, and technological contexts were examined. The goal is to outline the different agricultural tasks that were required for the creation of landscape features, and were afforded by their creation. These landscape features are associated with specific tasks based on what was required to create them, and what tasks they afforded, based on 

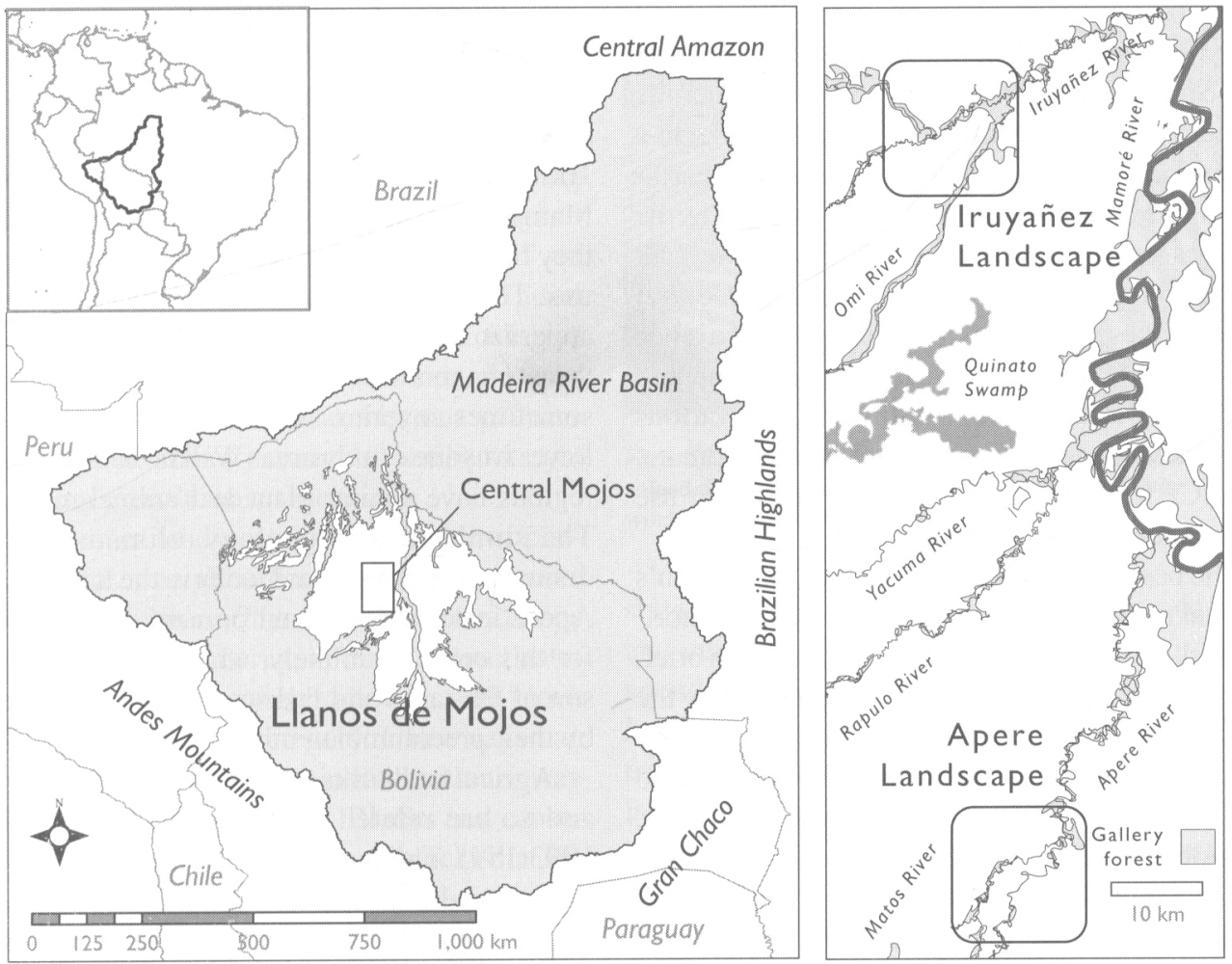

Figure 1. The location of the central Llanos de Mojos, including Mojos, the Madeira River Basin, and South America.

ethnoarchaeological, ethnohistoric, agronomic, and archaeological data. The interlocking schedule of farming, hunting, and fishing tasks maps onto a multipurpose infrastructure of field platforms, canals, and causeways. Relationships between types of features are considered from each of the two landscapes. Differences between the taskscapes are then compared, and the relationship between landscape/taskscape complexity and sociopolitical complexity is considered. These differences and this relationship are used to make a comparison between two landscape histories.

\section{The Central Llanos de Mojos}

The case studies come from an unlikely setting: the seasonally inundated tropical savanna in Eastern Bolivia called the Llanos de Mojos (or Mojos; Figure 1). Mojos is a seasonally flooded tropical savanna, crossed by dozens of small rivers, larger tributaries, and the Beni, Itenez (or Guaporé), and Mamoré rivers. Rainfall is strongly seasonal, with peak totals in January, and very little rain in July and August. Permanent and seasonal wetlands are interspersed with forested high ground and gallery forests. River meanders and oxbow lakes continually reshape the landscape, and the levees left behind by ancient rivers add to the complexity of the flat terrain. The result is a mosaic of landforms, strongly affected by seasonal flows of water and rains. Mojos is located entirely within the tropics, and the Mojos biota includes a variety of wetland species, birds, snakes and amphibians, and fish.

The ethnohistoric and linguistic record for Mojos is complex (Block 1994; Crevels and Van der Voort 2008; Denevan 1966), and includes several ambiguous terms. Mojos is used here to represent the entire Llanos de Mojos as a geographic region. Mojeño refers to precolumbian inhabitants of the region, making no interpretation of cultural or linguistic affiliation. Mojo is a term for an indigenous language classified as Arawak, spoken by many groups in the Jesuit missions of the seventeenth and eighteenth centuries. 
Mojos is noted for extensive and well-preserved remains of precolumbian agricultural infrastructure. Spread across an area as large as Syria or the Yucatán peninsula, Mojeños built earthworks in a wide variety of forms. Many well-preserved earthworks are located in the savannas and along the gallery forests of the tributaries of the west bank of the Mamoré River (or more simply Central Mojos). These earthworks have been known since the 1960s, and the pace of archaeological research in the area is increasing. Earthworks of various types in Mojos have been reliably dated from ca. $900 \mathrm{BCE}$ to $1500 \mathrm{CE}$ and it is likely that their use extends further back into time.

The best overview of Mojos remains Denevan's original monograph, although superb ethnohistorical work has been carried out (Block 1994). In brief, there were six prominent "tribes" described by the Jesuits in their seventeenth-and eighteenth-century accounts that still exist: the Arawak-speaking Mojo and Baure, and the Movima, Cayuvava, Canichana, and Itonama, each of which speaks an isolated language. Linguistic research is burgeoning, and it appears that Mojos is one of the places within South America in which the diversity of unrelated languages is very high (Crevels and van der Voort 2008). Remains of earthworks are widely distributed across the entire region, and there are important regional differences between these earthworks. These distinctive areas include large raised fields in north-central Mojos, causeways, raised fields and canals in the south, large mounds in the southeast, ring ditches and causeways in the northeast, and mound fields in the west. Although earthworks had a variety of potential functions, the improvement of soil conditions for agriculture was clearly of primary importance (Erickson 2006b). The societies of Mojos are exceptional cases in early classifications of South American cultures, described as chiefdoms and classified with circum-Caribbean chiefdoms (Steward 1946; Steward and Faron 1959). The Jesuit missions were established in the late seventeenth century, leaving a 200 -year transitional or protohistorical period during which connections between particular communities and the landscape must have changed. Nevertheless, it is clear that earthworks in Mojos are associated with the indigenous people living in the Beni today. More detailed summaries of the archaeology of Mojos are available elsewhere (Erickson 2006b; Walker 2008).
Earthworks along two rivers are considered, the Iruyañez in the north and the Apere in the south (Figure 1). The two landscapes are both located in seasonally inundated savanna. They are less than $100 \mathrm{~km}$ apart, they are both tributaries of the Mamoré, preservation conditions are similar, and they have similar histories of occupation and land use. The annual inundations of the two regions appear to be similar, with inundation moving from the permanent wetlands up toward the river levees, sometimes covering as much as 50 percent of the lower Iruyañez study area (Walker 2004). The two regions have similar plant and animal resources. The similarities in geology, climate, rainfall, drainage, vegetation, and fauna in the Iruyañez and Apere make strictly environmental explanations for this contrast unlikely, which invites comparison of the tasks and taskscapes that were created by their precolumbian inhabitants.

Agricultural tasks take place in time and space, and so are related to temporal cycles (Ingold 1993:159). The most insistent rhythm in Mojeño life is the alternation between inundation (February) and drought (August). Inundations move from the lower backslopes toward the high ground adjacent to the river, but also on occasion top these levees from the other side and inundate the landscape from the river (Erickson and Walker 2009). Temporal cycles of crops are highly variable because tropical farmers manipulate trees, annuals, and plants (such as manioc) that are continuously grown and harvested. The temporality of fish and animal life cycles is also important because use of these resources depends not on the domestication of individual species, but of the landscapes in which they move.

\section{Methods}

For each landscape, a summary description is presented, followed by more detailed descriptions of each of the patterns of earthworks that were observed and measured within the sample. These patterns were defined through spatial analysis of mapped earthworks. The GIS helps quantify relationships between different spatial units and types of spatial units within the landscape. Earthworks were traced directly from georeferenced aerial photographs obtained from the IGM in Bolivia, and other features, including rivers and forests were 
traced from public domain satellite imagery on Google Earth. Currently a community of students (Proyecto Arqueológico SIG del Beni/PROSIGAB) is measuring raised fields and other landscape features, recording results in a GIS database using ArcGIS. Despite the widespread archaeological evidence of intensive agriculture, there is no detailed ethnographic or historical record of raised field agriculture in Mojos, so general analogies between particular earthworks and communal tasks are required. Only the least ambiguous patterns (individual platforms, for example) can be thought of as having precolumbian meaning.

The Iruyañez landscape has four patterns: platforms, platform neighborhoods, platform groups, and platform divisions. The Apere River landscape has seven separate patterns, in three distinct categories: blocks, block neighborhoods, and block divisions form the first category. Causeways can be grouped at two levels: the individual causeway and the network of causeways. Blocks and causeways are integrated in the groups of blocks that are defined by the hydraulic catchment of a causeway (block-causeway neighborhoods), and groups of blocks that are bounded by causeways (blockcauseway divisions). Measurements for each type of earthworks are summarized, and the tasks that are associated with it, the tasks that it affords, and the tasks that impact other tasks are all enumerated. Landscape features are presented by region, and then the two regions are compared.

\section{Iruyañez River}

Along the Iruyañez River, earthwork forms are homogeneous (Figures 2, 3; Figure 4, top)-originally described as "large raised fields" (Denevan 1966). Farmers built fields on the high ground bordering the gallery forest. Small seasonal creeks interrupt these high areas every kilometer or two. During the rainy season, inundations cover much of the landscape, while for the most part earthworks remain dry. Although datable remains are difficult to obtain from excavations, earthworks have been dated through association with settlement. Two settlements along the river are well dated, San Juan (BYA122) (5 dates, 1475-1560 B.P.) and El Cerro (BYA107) (8 dates, 470-620 B.P.), both along the lower Iruyañez River (Walker 2004:74). Both of these settlements are directly adjacent to raised fields. Test excavations at Cerro

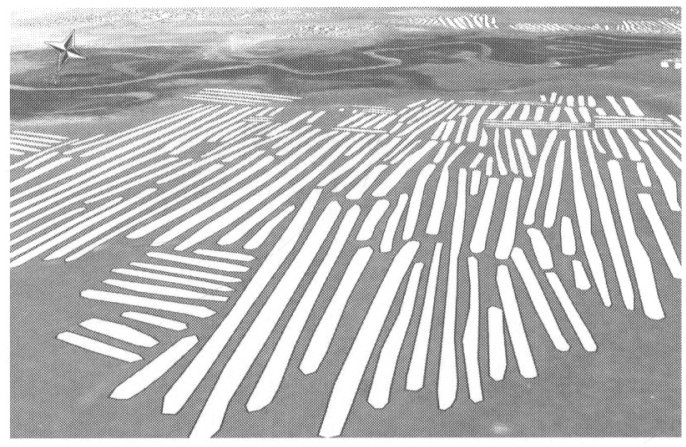

Figure 2. Aerial photograph combined with digitized large raised field platforms along the Iruyañez River (earthworks were digitized by Chris Gilhooley).

showed an area of dark soil, charcoal, burned clay, and ceramics $565 \mathrm{~m}$ across, which could correspond to a sizable village or town. San Juan is located within a forest island of similar size, but transects of test excavations did not bisect the island, so the size of the settlement cannot presently be determined. San Juan is located within the measured sample of raised field platforms, and is near to some of the largest fields in the area. Large raised fields are associated with both locations, suggesting that farmers used raised fields on this landscape over the course of at least 900 years. Links between excavations in raised fields, ceramics, and settlement are explored in more depth elsewhere (Walker 2004, 2011, 2012).

Platforms (Figure 4, center right). Platforms were measured directly in ArcGIS from digitized aerial photographs. A sample of 1,665 platforms ranged between .016 and 2.707 ha in area, with a mean of .316 ha, and a standard deviation of 277 . Individual platforms are long and narrow, averaging $20 \mathrm{~m}$ wide by $200 \mathrm{~m}$ long, and $40 \mathrm{~cm}$ tall, although some are longer than a kilometer. Each platform differs from its neighbors, both in size and orientation. Farmers built these as individual constructions. They are not uniform in size or orientation and farmers placed some of them on the landscape in helter-skelter fashion.

Platform neighborhoods (Figure 4, bottom right). A platform neighborhood represents a single platform and the immediately adjacent platforms. To determine adjacency, a "buffer" was calculated in ArcGIS for each platform such that the area of the buffer was equal to the area of the platform, a rough simulation of the area from which 


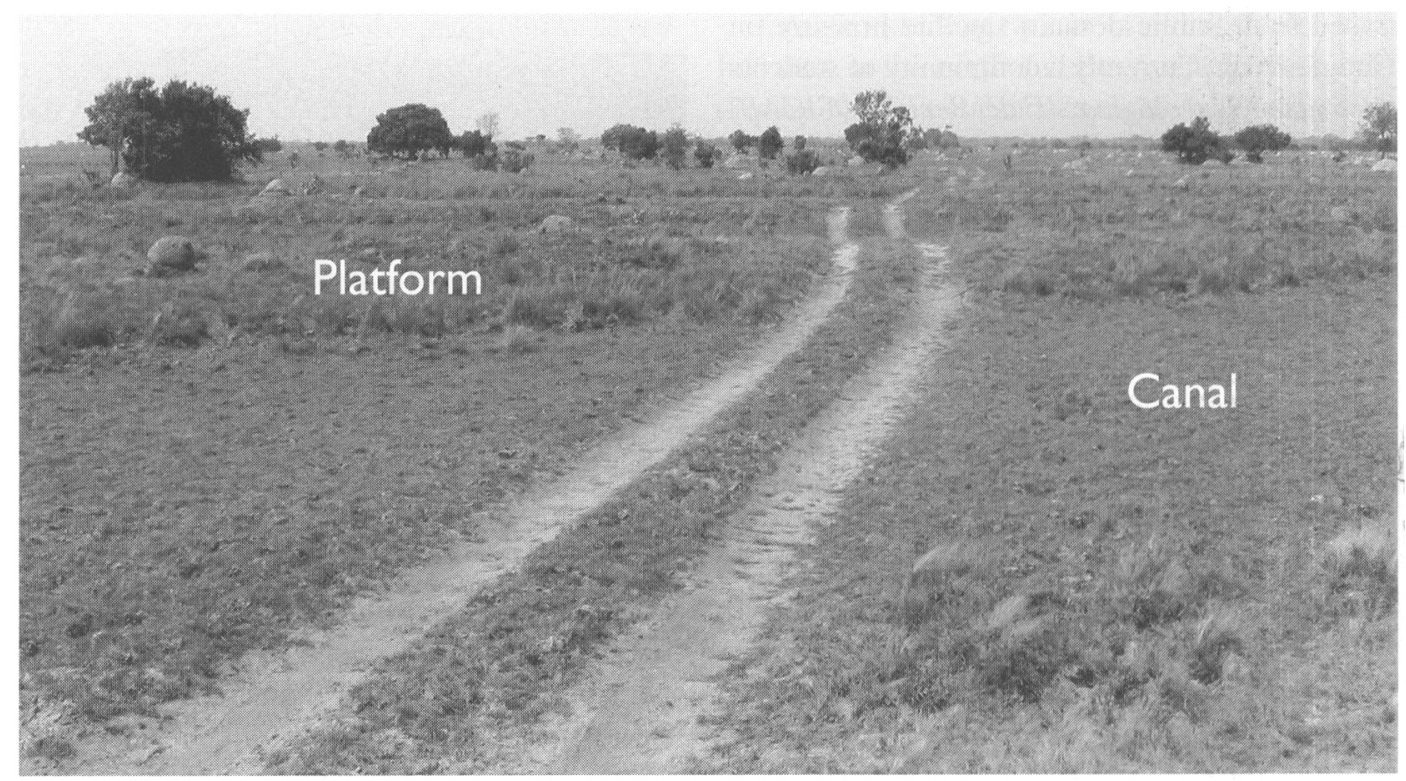

Figure 3. Raised fields near the Iruyañez River, crossed by a dirt road or oxcart trace. Overlaid text indicates the loca* tion of platforms and canals (or negative space).

soil for the platform was gathered from the immediately adjacent savanna. A platform neighborhood therefore consists of a central platform, and all surrounding platforms whose buffer overlaps with that of the central platform. Platform neighborhoods were calculated for all 1,584 platforms with neighbors within the mean value for equal area buffer for the entire sample $(7.12 \mathrm{~m})$. A platform neighborhood represents a single platform and the neighboring platform on which its construction and use had a direct effect. Platform neighborhoods ranged from .105 ha to $7.990 \mathrm{ha}$, with an average of 1.420 ha, and a standard deviation of 1.03 .

Platform groups (Figure 4, center left). Members of a platform group are adjacent (as defined by overlapping buffers, see above) and share the same orientation. Platform groups were generated using the equal area buffers used to define platform neighborhoods, after first dividing all platforms into two classes based on orientation: north-south and east-west. Groups were defined as those platforms with overlapping equal area buffers, in the same orientation class. Single platforms were not counted as groups. A sample of 137 platform groups ranged from .061 ha to 80.342 ha, with a mean of 3.697 ha and a standard deviation of 9.475 . An independent sample of 30 platform groups based on similar criteria (but applied manually to a different measured sample of platforms) had a range of .64 ha to 17.43 ha, a mean of 4.97 ha, and a standard deviation of 4.79 (Walker 2004).

Platform divisions (Figure 4, bottom left). Platform divisions in the Iruyañez landscape are defined as areas of platforms (as defined by overlapping buffers) separated by open spaces (where buffers do not overlap). A total of 58 platform divisions range from .169 to 162.561 ha, with a mean of 94.140 ha and a standard deviation of 38.343 . Divisions are generated by separating the set of all platforms into divisions, separated where equal area buffers did not overlap. Blank spaces could be the result of differential preservation, and are not "intentional" in the same sense as spatial units bounded by earthworks. For example, some correspond to seasonal streams. They could be related through proximity to other features, like anthrosol deposits (interpreted as settlements).

Landscape (Figures 2, 3, 4). If we define the Iruyañez landscape heuristically by the presence of "large raised fields," it stretches for tens of kilometers along the Iruyañez and Omi rivers, and several of their tributary creeks. The landscape extends for kilometers outward from either side of each of the rivers, involved the movement of hundreds of thousands of cubic meters of soil, and covered tens of square kilometers. Platforms are oriented gen- 

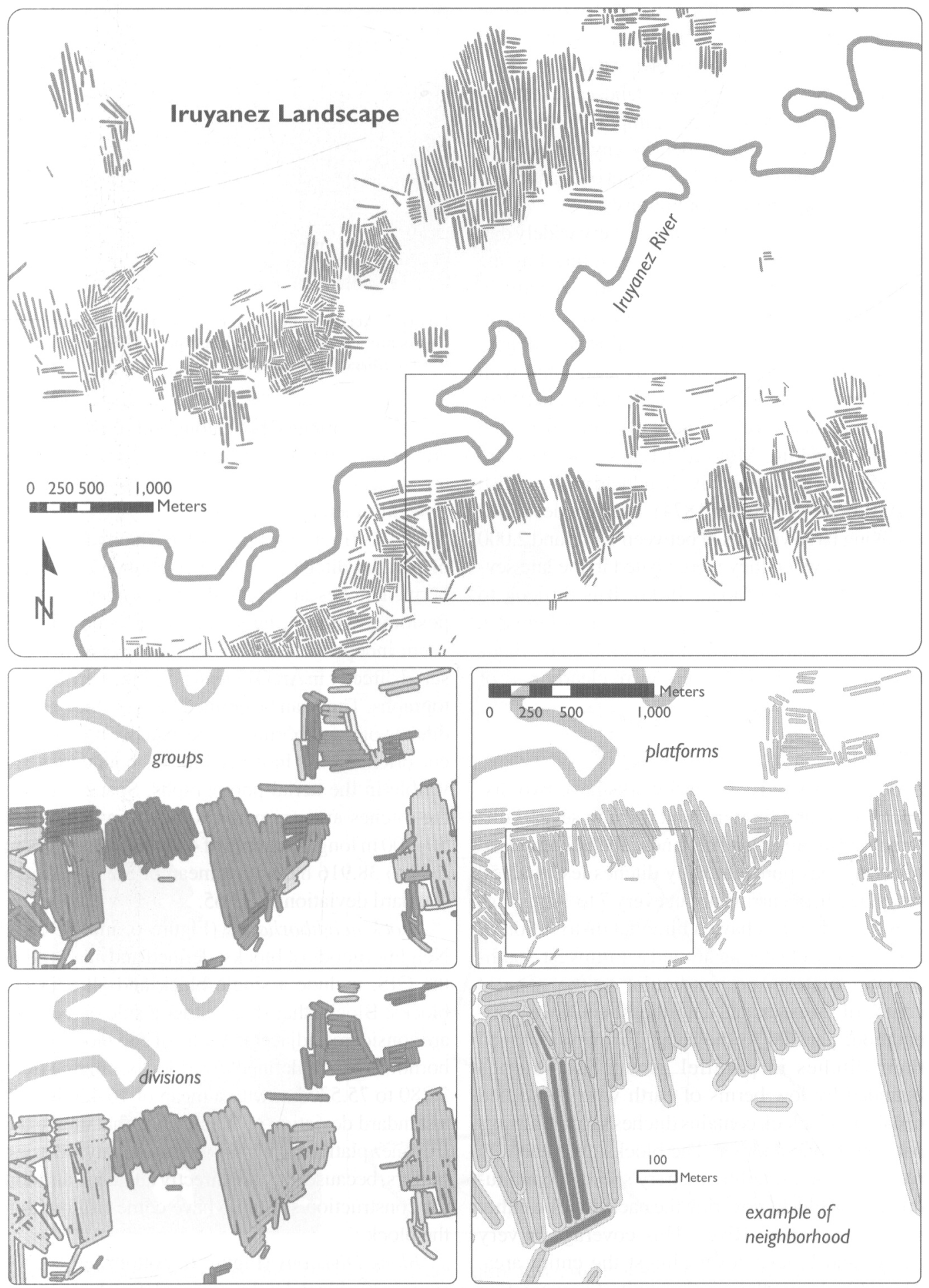

Figure 4. Schematic map of earthworks along the middle Iruyañez River, west of its confluence with the Omi River. Earthworks of a single form (large raised fields) are shown in the large map, and the four distinct arrangements of those forms are shown in the inset maps. These arrangements correspond to the measurements in Table 1 (earthworks were digitized by Chris Gilhooley). 
erally either perpendicular or parallel to the course of the neighboring river. The tasks associated with the entire Iruyañez landscape do not have any direct impact on tasks associated with landscape features in the Apere landscape. For example, the Iruyañez is not diverted or impounded by any earthworks, such that any part of it can be thought of as a "downstream" or "upstream" community.

Large raised field platforms are very widely distributed, from the large lakes (including Laguna Rogaguado) in the north to the Middle Yacuma in the south, a distance of about $100 \mathrm{~km}$. In Jesuit accounts (dating to about 1695), this central area of large raised field platforms is associated with Cayuvava speakers (Block 1994; Denevan 1966). The Cayuvava are not as well-known as the Arawak-speaking Mojo and Baure, but they are associated with a distinctive handheld basketry fish trap (Block 1994; Keller 1874). They are described as having large villages of between 1,800 and 2,000 inhabitants when they were visited in the late seventeenth century (Zapata 1906). It is difficult to establish direct historical connections between Jesuit descriptions and the precolumbian Iruyañez landscape, but the Cayuvava were clearly part of precolumbian Mojos.

\section{Apere River}

Along the Apere River earthworks have two distinct forms, and farmers built them in several different arrangements. The landscape is composed of open areas punctuated by ditches less than 50 $\mathrm{cm}$ in depth, occurring about every 7 to $10 \mathrm{~m}$ (Figures 5,6 ). Ditches have a bimodal distribution of orientations, clustering around a northwest-southeast orientation, perpendicular to the general course of the river, and a northeast-southwest orientation, parallel to the river. Farmers arranged their ditches in parallel groups, sometimes bounded by low berms of earth with associated canals. Each block contains ditches that are always parallel to one another. The blocks are generally rectilinear and satellite imagery shows a continuous area of blocks covering the backslope on either side of the Apere River. This coverage is very dense, and blocks cover almost the entire area. These blocks are the smallest unit of organization in the landscape that has a clear spatial definition, and likely held meaning for precolumbian farmers. Associated with these blocks of ditches are

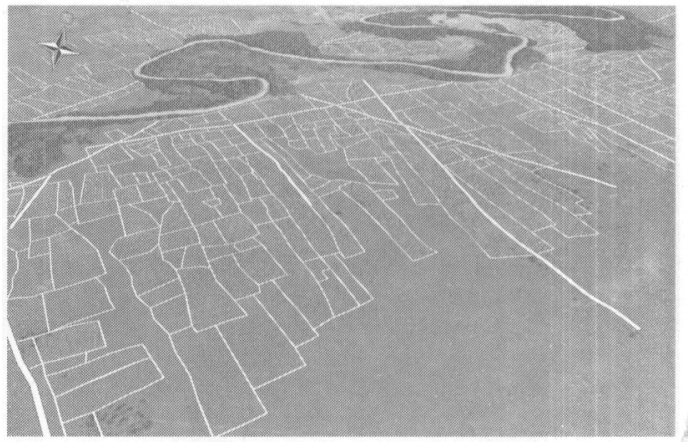

Figure 5. Aerial photograph combined with digitized field blocks and causeways along the Apere River (earthworks were digitized by the author).

causeways, oriented both along and across the general orientation of the river floodplain. Causeways are about a meter in height, and as long as two or three kilometers.

Blocks (Figure 6, upper left). Blocks are groups of parallel ditches, sometimes bounded by a low berm. Ditches are spatially determined by their positions within a larger block, and they do not occur independently of blocks. Blocks were measured directly in ArcGIS using digitized aerial photographs. They can be defined because the parallel ditches of neighboring blocks usually have different orientations. In other blocks, boundaries are visible in the aerial photographs. Space between the ditches average perhaps 7 or $8 \mathrm{~m}$ across and 50-100 m long. A sample of 428 blocks range from .189 to 38.916 ha, with a mean of 3.233 ha and a standard deviation of 3.065 .

Block neighborhoods (Figure 6, middle left). Neighborhoods of blocks, defined and analyzed in the GIS, include a single block and all adjacent blocks. Blocks that share either a side or a corner are considered adjacent. A total of 385 block neighborhoods can be defined from blocks, ranging from 2.280 to 75.530 ha, with a mean of 16.420 ha and a standard deviation of 9.620 . Note that unlike the Iruyañez platforms, blocks were not analyzed using buffers, because they are directly adjacent, and soil for construction seems to have come from within the block.

Block Divisions (Figure 6, bottom left). Divisions in the block landscape are defined as areas of contiguous blocks separated by open spaces. These blank spaces could be the result of differential preservation, and are not "intentional" in the same 

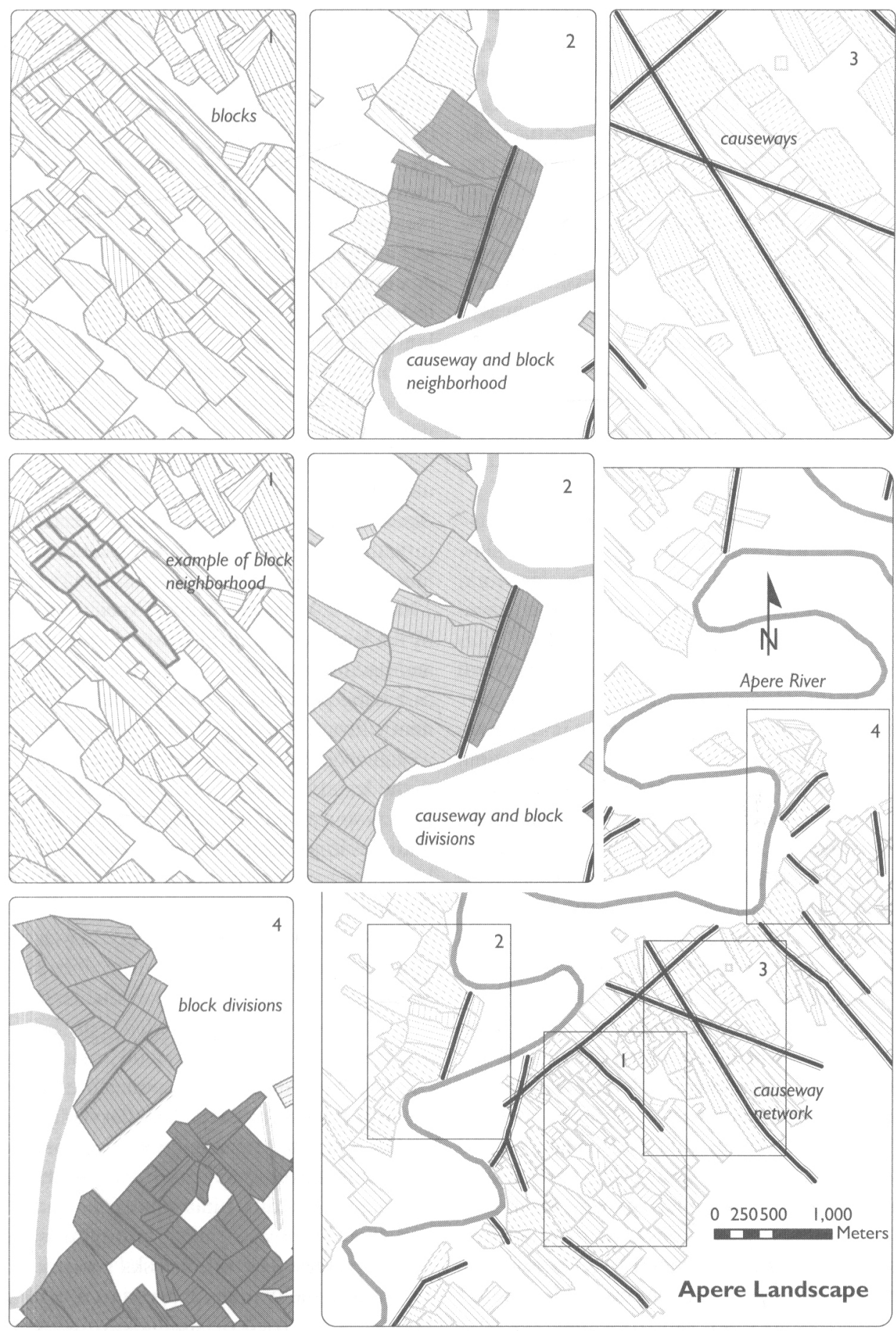

Figure 6. Schematic map of earthworks along the middle Apere River, south of its confluence with the Matos River. Earthwork forms (raised field blocks and causeways) are shown in the large map, and the seven distinct arrangements of those two forms are shown in the inset maps. These arrangements correspond to the measurements in Table 1 (earthworks were digitized by the author). 
sense as blocks or block neighborhoods. At least in some places they correspond to seasonal streams. They could be related through proximity to other features, like anthrosol deposits. A total of 29 block divisions range between .305 and 445.229 ha, with a mean of 44.423 ha and a standard deviation of 91.620 .

Causeways (Figure 6, upper right). Causeways represent a second category of landscape feature, distinct from blocks. In general, causeways are between .2 and $2 \mathrm{~m}$ tall, between 1 and $20 \mathrm{~m}$ wide, and accompanied by canals on one or both sides, as soils excavated from the canals were used to construct the causeway (Erickson and Walker 2009). A total of 27 causeways range from 277 to 2.508 ha in area, with a mean of .887 ha and a standard deviation of .567 .

Causeway network (Figure 6, lower right). Causeway networks are defined as groups of intersecting causeways. Only one causeway network was described, on the southeast bank of the Apere River. Its causeways span $9.279 \mathrm{~km}$ (which is 38.77 percent of the length covered by all measured causeways).

Causeway-block neighborhoods (Figure 6, upper middle). By comparing causeway orientation to the orientation of ditches in raised field blocks on either side of the causeways, it appears that some causeways were integrated into the blocks with some regard for their orientation. Causeways generally parallel or cut directly across ditch orientations in neighboring blocks. Causeway-block neighborhoods are patterns that combine causeways and blocks, related through proximity. Each causeway-block neighborhood consists of one causeway, and all neighboring blocks. Of the 29 causeways, 23 intersected blocks to form causeway-block neighborhoods, ranging from 3.690 to 74.430 ha, with a mean of 21.079 ha and a standard deviation of 17.926 .

Causeway-block divisions (Figure 6, center middle). Causeway-block divisions are defined as areas of continuous blocks bounded by two or more causeways. The measured causeway-block divisions do not include several likely units, because of the "edge effect" of the limits of the digitizing, just as with the platform divisions along the Iruyañez. In other words, some divisions lie partly within and partly outside the measured earthworks. A total of 27 causeway-block divisions can be defined, ranging from 1.300 to 174.660 ha, with a mean of 38.330 and a standard deviation of 45.490 .

Landscape (Figures 5, 6). If the Apere landscape is defined heuristically by the presence of blocks and causeways, then it was tens of kilometers long, tens of kilometers wide, involved the movement of hundreds of thousands of cubic meters of earth, and covered hundreds of square kilometers. The tasks associated with the entire Apere landscape do not have any direct impact on tasks associated with landscape features in other landscapes, including the Iruyañez landscape. Blocks and causeways are oriented generally either perpendicular or parallel to the floodplain of the neighboring river.

Causeways and blocks are very widely distributed, from near San Borja in the west to the upper Apere in the south and east. In the seventeenth century, the middle Apere was associated with Mojo and Movima speakers (Block 1994; Denevan 1966). The Mojo are Arawak speakers described by the Jesuits as "civilized," wearing cotton clothes and having permanent chiefs. They are described as having permanent political leadership, permanent villages, and organized religion in the form of a "jaguar" cult. The Movima were less well-known to the Jesuits, but were described as accomplished potters and fierce enemies of the Cayuvava. As with the Iruyañez, it is difficult to establish direct historical connections between Jesuit accounts of the Mojo and Movima and the precolumbian Apere landscape, although they were clearly present in precolumbian times.

\section{Tasks and Taskscapes}

Iruyañez and Apere landscape features are linked to tasks in four ways, from smaller scales to larger scales. First, the Apere landscape is organized into larger minimal units than the Iruyañez. Second, the two landscapes differ in terms of the number and variety of tasks associated with particular landscape features. The list of tasks presented below for each of the two landscapes is similar because both are composed of similar earthworks. More tasks are linked to the Apere landscape because of the different tasks that causeways both require and permit. The third comparison is the degree to which tasks interlock to form a complex taskscape. The Apere is qualitatively different, because on the 
Apere the tasks associated with two different kinds of earthworks interlock to form a more complex taskscape. Finally, the total amount of labor invested in the construction of each of the two landscapes is broadly similar.

The Apere landscape is organized at a larger scale than the Iruyañez. The Apere sample has minimal units (blocks, $n=428$; mean $=3.23$ ha; $\max$ $=38.92$ ha) that are roughly ten times larger than the minimal units of the Iruyañez (platforms, $n=$ 1,665 ; mean $=.32$ ha; $\max =2.71$ ha) both in terms of average and maximum area. Farmers along the Iruyañez used platforms to move water over the course of tens of meters, but farmers along the Apere used causeways to move water over the course of thousands of meters.

Second, each landscape can be thought of as the product of labor, quantified based on the amount of earth moved. A detailed comparison of earth moving experiments can be found elsewhere (Walker 1999) but a simpler comparison will suffice. Labor costs relate to the total volume of earth in the various earthworks. Although the Iruyañez raised fields require more earth to be moved per unit area, the platforms are in some cases more widely spaced, and as the two landscapes cover similar areas (about $65 \mathrm{~km}^{2}$ ) the amount of labor per unit area required to build them was also similar. The amount of labor per worker or per unit of time is of course much more difficult to determine.

The final comparison is the number and variety of tasks associated with the landscape, linked through specific analogy to the number and variety of landscape features (Table 1). The six categories of tasks described below are farming, construction and maintenance, hunting and fishing, water management, fire management, and transportation.

Farming refers to such tasks as soil preparation, green manuring, planting, weeding, pruning, splash irrigation, and harvesting. These tasks generally take place at a smaller spatial scale than the other classes. Specific analogies can be drawn from agronomic studies in the Beni today, as well as experiments that seek to replicate the conditions on precolumbian raised fields (Arce 1993; Boom 1986; Pérez-Chávez 1997; Piland 1997). Even though modern farming in the Beni differs in terms of crops, economic context, and organization of labor, the study of contemporary agriculture is still the best source for analogies. Although raised field agriculture is not described, additional information is also available from ethnohistoric sources (Block 1994; Eder 1985 [1791]; Zapata 1906 [1693]). Pollen from excavated field platforms elsewhere in Mojos indicate that fields were probably multicropped (pollen recovered included huallyusa (Xanthosoma sp.), hierba mate (Ilex paraguayensis), and achiote (Bixa orellana) (Erickson 2006b). Today, rice, sugar cane, bananas, maize, and manioc are all cultivated for market and for consumption, although many other crops are known. It may be possible in the future to associate particular earthwork types with particular crop regimes. For example, some earthwork types might be more suitable for huallyusa, while others might be more suitable for manioc.

The term "construction" refers to tasks of excavating, moving soil and building earthworks, as well as maintaining them against erosion and clearing canals. Our knowledge of these tasks comes from the same agricultural experiments, as well as experimental work from other South American contexts (Erickson and Candler 1989; Kolata et al. 1996). Some ethnohistoric sources refer to group agricultural work (Zapata 1906 [1693]). The energetics of excavation and earthmoving in tropical contexts have been analyzed by several authors (Atkinson 1961; Denevan 1982; Erasmus 1965; Golson and Steensburg 1985). Soils for raised field and causeway construction are assumed to be taken from adjacent excavation, suggested by the pairing of raised causeways and platforms with excavated canals or "negative space." Construction in Mojos may have been easiest in the spring and fall, when clayey soils are softened by rain, but not inundated.

Hunting and fishing refers to a wide variety of techniques for capturing land animals such as tapir (Tapirus terrestris), spider monkey (Ateles sp.), brocket deer (Mazama sp.), armadillo (Dasypus novemcinctus, Dasypus septemcinctus) and capybara (Hydrochoerus hydrochaeris), large fish such as surubí (Pseudoplatysoma fasciatum), tucunaré (Cichla sp.), pacú (Colossoma macropomum) and palometa (Serrasalmus nattereri), but also animals such as frogs, small fish, invertebrates and other fauna associated with the microenvironments created by and in fields and canals. Hunting and fishing in eastern Bolivia are well studied (Chicchon 1992; Holmberg 1950; Stearman 1987, 1991; Townsend 1995) even if these studies have not 


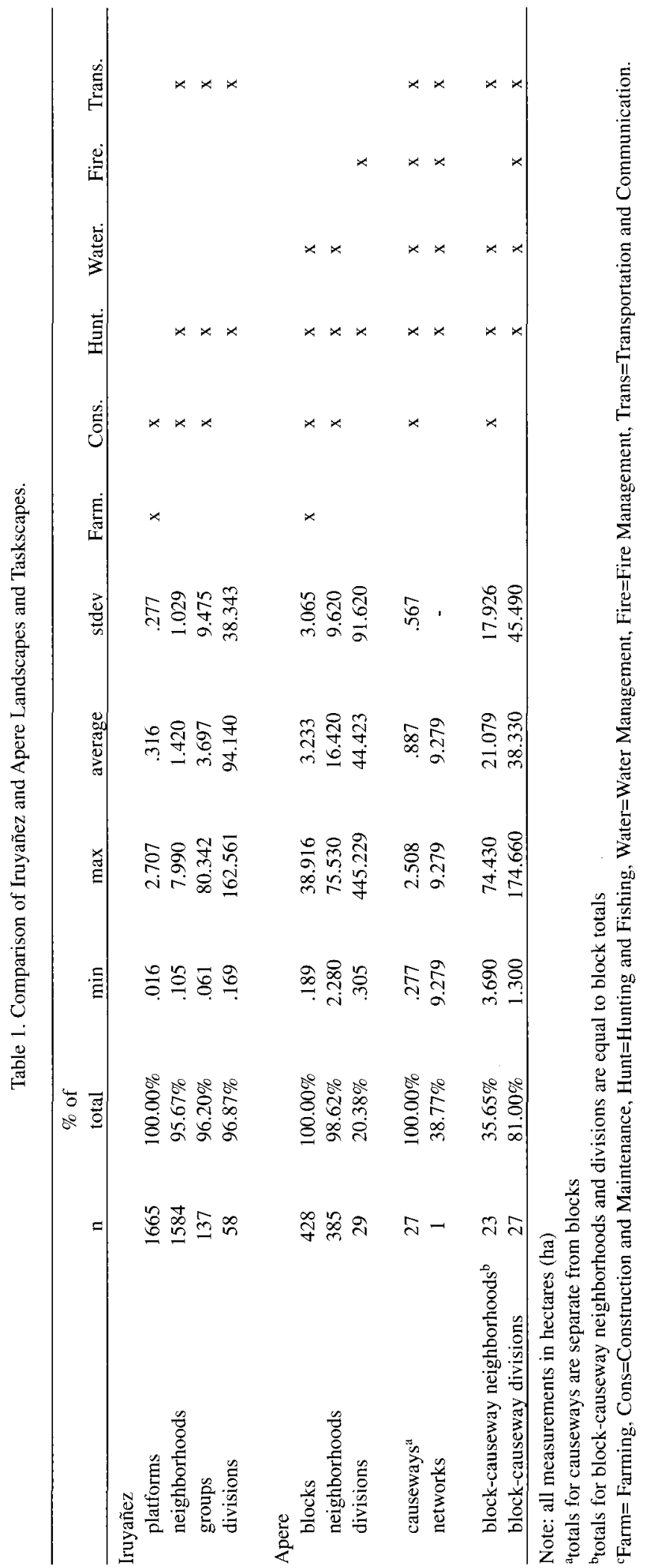


explicitly examined the effects of raised fields or causewayed landscapes (although see Erickson 2000). During 15 consecutive months of fieldwork in 1996-1997, the author participated in a range of hunting and fishing activities, including fishing in both riverine and savanna environments. A variety of fish emerge from the rivers out into the savanna in the wet season, and when inundations recede, large numbers of fish (such as surubí) are stranded in oxbow lakes and ponds.

Water management refers to the allocation and movement of water through canals and negative spaces associated with raised fields and causeways, controlling water as it moves onto the landscape and off. A few studies model the control of water in Mojos (Erickson 2006b; Erickson and Walker 2009) and studies of flood recession farming are also relevant (Park 1992). The observed experience of modern road builders and ranchers, planning for water retained by elevated roads, and using simple dams to impound water for cattle, demonstrates how water flows are affected by earthworks (and vice versa).

Fire management refers to lighting and organizing fires, used in the savanna today to clear areas of grass and promote new growth. Fire has a significant role in shaping Mojos (Erickson 2006b; Hanagarth 1993; Langstroth 1996) and its role around the world is increasingly appreciated (Kull 2009; Pyne 2001). Mapping of burned areas from LANDSAT imagery is also relevant; burned areas over $10 \mathrm{~km}$ in length, and greater than $10 \mathrm{~km}^{2}$, are quite common. In the past, fire likely played a key role in the maintenance of the savanna kegetation, and could have had a role in communal hunting.

Transportation refers to tasks associated with the movement of people, agricultural produce and other objects across the landscape. These tasks are known primarily through working and living along the Iruyañez and repeating trips during the dry season (on foot) and in the wet season (by canoe) (Denevan 1966; Erickson 2006b; Erickson and Walker 2009; Trombold 1991). Wet season travel is in general easier. Even a small dugout canoe can move ten people easily, or a metric ton of cargo, and reach deep into the flooded savanna along small creeks and canals. The transition between wet and dry seasons is geographically complex, both because of earthworks and because dugout canoes can use even very shallow expanses of water. Causeways provide ease of ground transportation year round.
Carrying out archaeological survey since 1992, the author has accumulated experience traveling on foot and by canoe through both the Apere and Iruyañez landscapes.

In Table 1, landscape features from both rivers are analyzed in combination with these six categories of tasks. Each mark represents a feature of the taskscape-a pattern of landscape features where a particular category of task took place. For example, on the Iruyañez, construction and maintenance tasks are associated with individual platforms, a connection based on their spatial independence. Platforms vary by orientation and length, suggesting their construction was individually determined. Also, the maintenance (using neighboring canal soils to renovate and raise the planting surface) and improvement of soil took place at the scale of the individual platform. A second Iruyañez example is the set of construction and maintenance tasks associated with groups of platforms. These groups have a distinct spatial pattern, and the comparison between the size of the largest platforms in the group and the total platform group size suggests that they might have been associated with groups of between 20 and 100 people (Walker 2000, 2001, 2004). Decisions about construction and maintenance were made at this spatial scale as well. These two sets of tasks are potentially in conflict, in all places where a platform is a member of a group. People working within the Iruyañez River taskscape must have negotiated these conflicts (among others) in order to carry out these tasks. The Iruyañez taskscape centers around these issues of construction and maintenance, as well as hunting and fishing.

When Iruyañez farmers built a platform, they coordinated its construction with the farmers of adjacent platforms, to ensure enough room to provide fill for construction, organic material for green manure, and space for fish, waterfowl, and other animals. Construction and maintenance tasks had little other influence on nearby platforms. The same is true for neighborhoods or platform groups. In addition, groups of platforms could have created habitat for pests (or prey) and different fire conditions. The effect of these factors on tasks associated with individual platforms, neighborhoods, and groups are not easily visible, and not as tangible as the potential conflict between tasks associated with neighboring platforms. 
On the Apere, water management tasks were associated with individual field blocks. Water drained within the block through parallel ditches, and was contained by a berm, meaning that water management tasks, allowing water in and out of the block, for example, were undertaken at this scale. At the same time, water management tasks were associated with causeways. These tasks included the drainage and movement of water up and down the backslopes, as well as the allocation of water to different blocks. When these two sets of tasks coincided at the same time and place, at the intersection of a causeway and a block, the execution of those tasks created a conflict. The inhabitants of the Apere River taskscape must have negotiated conflicts over water, where blocks and causeways were adjacent. Even where blocks and causeways were unconnected, the causeway drainage lowered the water table and affected the movement of water.

When Apere farmers built a new block or causeway, they coordinated its construction with the farmers of adjacent blocks in order to resolve conflicts about construction material-for example, the effects of drainage from one block on the drainage of the neighboring blocks. With causeways (and their attendant canals), the tasks associated with neighboring blocks of fields was significantly altered by being in proximity to a causeway. Causeways made some tasks (transportation, communication, ritual) significantly, perhaps decisively, easier. If causeways were part of larger network of causeways connecting river, backslope, fields, and settlements, then the landscape was both conditioned and maintained by a network of tasks that interlocked in space and in time. Although this could also have been true along the Iruyañez, in the Apere landscape it can be seen in the landscape.

Conflicts between different kinds of tasks that use the same landscape elements are specific illustrations of the general complexity of the taskscape, and of the difference between the two cases. On the Iruyañez, platforms affected farming, construction, and maintenance tasks. Platform neighborhoods affected construction and maintenance, hunting and fishing tasks, as well as transportation. Hunting and fishing rights were negotiated across boundaries between neighboring platforms, when prey moved between them. The movement of people and goods to and from platforms depended on access via water or across other platforms. Platform groups may have been related to construction and maintenance tasks and were certainly related to hunting and fishing tasks, just as with platform neighborhoods. Platform divisions are of much larger scale and are associated with hunting and fishing tasks, including larger communal hunts and fishing, as well as the potential use of fire to clear areas or drive game. They are also associated with transportation tasks, including moving people and goods over long distances.

On the Apere, blocks affected farming, construction and maintenance, hunting and fishing, and water management tasks. Because blocks are both long and wide, they provided space (especially when fallow) for both land animals and fish. Block neighborhoods affected hunting and fishing tasks, because the constituent blocks share both boundaries and canals, which also means that they were essential to water management tasks, at the smallest scale. Block divisions might be associated with hunting and fishing tasks for the same reasons that block neighborhoods are. Because of their size (up to several square kilometers), they are also associated with the management of fire. Intentional burns of the savanna today are rarely smaller than a square kilometer, and can cover many square kilometers in a single event. Causeways are associated with construction and maintenance tasks, as the second type of basic landscape unit. They are also associated with water management, as conduits for water, as well as boundaries for water control. They created long-distance paths for both canoe and foot traffic. The single observed causeway network was also concerned with water management and transportation tasks, at a larger scale, that connects more tasks. Causeway-block neighborhoods change hunting and fishing tasks, because land animals and fish are affected by causeways and canals. The water management of blocks and causeways was interdependent, as is the management of fire within or on these landscape features, or its protection from fire, since both water and fire cannot easily cross causeways (something which can be verified on LANDSAT imagery). Transportation tasks involving both causeways and blocks were also affected by causeway-block neighborhoods. Finally, causeway-block divisions (as opposed to causeway-block neighborhoods) may have functioned as distinct districts for the management of water and fire. 
In sum, the taskscape is characterized by fewer overlapping tasks on the Iruyañez. The connections between larger units and specific tasks is clearer on the Apere. We may conclude that there were fewer occasions for coordinating labor on the Iruyañez, not only in the process of construction, but also in the process of maintenance and regulation of the landscape. It is difficult to imagine why farmers had to cooperate after building and maintaining their platforms. On the Apere, the landscape is connected to a larger number of overlapping tasks. First is the scale of the individual block, and second the scale of the individual causeway, affecting at least the blocks that are immediately adjacent to it. Because blocks cover the savanna without a break, the connection between adjacent blocks is also stronger than the connection between adjacent platforms in the north. Blocks have a stronger connection to one another than do platforms. As a result, there were more occasions for coordinating tasks, not only in construction and maintenance, but also in the regulation of relationships between blocks and causeways. From a taskscape perspective, the comparison between the two landscapes is the number of combinations of landscape features and tasks, and most importantly, of the number of conflicts between these combinations. If someone set out to build a raised field, or to hunt, there were more potential conflicts with these tasks on the Apere landscape than on the Iruyañez landscape. In this sense, the taskscape of the Apere landscape was more complex than that of the Iruyañez landscape.

Comparison shows that although the two landscapes represent comparable investment of labor, labor was organized in more complex ways on the Apere: split among more tasks, demanding the scheduling of more activities in more places. What makes the Apere landscape qualitatively more complex is that two kinds of earthworks are interlocked, with more conflicts between different communal tasks. The constituent features of the landscape and the constituent tasks of the taskscape were larger on the Apere than on the Iruyañez. Communities associated with the Apere landscape were able to schedule and solve the problems associated with a more complex taskscape, while the communities associated with the Iruyañez landscape did not. In this sense, Apere sociopolitical organization accomplished more than Iruyañez sociopolitical organization. It is also possible to characterize the history of the two landscapes. This brings the analysis to the question of how these taskscapes changed over time.

\section{Discussion}

The difference between these two landscapes shows that a range of alternatives were constructed, in similar environmental settings, using similar technologies. Similarities in geology, climate, rainfall, drainage, vegetation, and fauna in the Iruyañez and Apere make strictly environmental explanations for this contrast unlikely. In both cases, farmers faced similar problems of inundation and drought every year. Both groups of farmers invested in landscape capital over an area of tens of square kilometers, over periods of more than 900 years. If more agricultural and organizational problems were solved in order to build and sustain the southern landscape than was the case in the north, then perhaps the difference is between a more complex society on the Apere than on the Iruyañez. The Apere landscape could be more complex because it was created and built under the aegis of a specific kind of sociopolitical organization. The difficulty with this interpretation is that even when analogies can be drawn between specific elements of the landscape (platform groups on the Iruyañez, for example), those groups cannot be easily associated with a single type of sociopolitical organization. A platform group could be taken as evidence of an autonomous local group, or as a subordinate unit in a state-level organization. The difference is difficult to establish because it is not clear that specific kinds of sociopolitical organization have one-to-one correlates in spatial organization. State-level organization might be correlated with landscapes and taskscapes that are more complex, but this assumption is brought into question by examples of state-directed agriculture that make the landscape simpler, or more legible (Scott 1998; Yoffee 2005). Once the potential of local organization to construct and maintain infrastructure is recognized, the interpretation of spatial patterns becomes more difficult.

Momentarily tabling this question of classification, an alternative is to interpret these differences as reflecting a historical difference: a distinction between two areas where different tasks related to farming, hunting, fishing, water and fire 
management, and transportation, were organized in different ways over many generations. The Apere taskscape could have been more complex because it represents a longer history of agricultural change. However, the Iruyañez landscape also has a long agricultural history. These landscapes could have been home to several groups of people simultaneously, and solving some conflicts in the taskscape may have involved not just different economic systems but different linguistic or ethnic groups. The Apere landscape may have been farmed, hunted, and fished by a greater variety of different communities, or by more than one contemporaneous community. Finally, the Apere taskscape could have been more complex because of crop selection, cuisine, economics, trade, language, settlement, transportation, hunting, fishing, or forestry. Further mapping of the landscape, the refinement of these analogies, and correlations with excavated settlements may help us understand these factors and resolve these issues.

In light of this set of differences, we can return to the sociopolitical question and consider the interaction between these two taskscapes and attempts to centralize or control them. Although they represent the same investment of labor per unit area, the Apere has minimal units (blocks) that are roughly ten times larger than the minimal units of the Iruyañez (platforms). When units are matched up to agricultural tasks, this suggests that Apere agriculture was organized at a larger scale than Iruyañez agriculture. Such units represent successful and sustained organization of communal labor. Political actors that did not participate in the taskscape had to enlist or subvert the local organizations that built and maintained these landscapes. If they did so, such actors faced an easier political situation along the Iruyañez, where alternatives were fewer, than along the Apere, where people were already working in groups that interacted with and depended on one another to schedule more tasks and solve more agricultural problems. The solutions that farmers build into their fields and their relationships with one another form landesque capital. This is the source of their ability and need to maintain a social and political life independent of a "chiefdom" or a "state."

The creation of landesque capital is a widespread phenomenon, with impressive results. In the Near East, for example, irrigation infrastructure is widespread and very old (6000 B.C. and earlier), predating the establishment of states or other centralized political systems (Trigger 2003; Wilkinson 2003). Trigger concludes that early states are not usually interested in managing flows of water or labor through such irrigation systems. Instead, they are interested in managing the flow of tribute that derives from them:

Productivity ultimately depended on the knowledge, labour, and skills of individual farmers. Their thorough familiarity with locally effective agricultural techniques and the local environment allowed these farmers to increase productivity fairly easily when social conditions required them to do so or rewarded their efforts [Trigger 2003:397].

The productivity of agricultural systems does not depend on centralized authority, and successful states tend not to meddle with agriculture.

Sociopolitical organization of agriculture must have solved these coordination problems, because the landscape and taskscape were sustained for many generations, along both rivers. No matter what other kinds of activities took place (organized violence, religion, or trade), agricultural tasks maintained their dialectic relationship with the landscape. To study agricultural changeintensification, extension, and abandonmentanalysis begins with local histories of agricultural work, not the impact of political control from outside the system. Even when agricultural decisions are affected by the state or the market, those histories shape agricultural change in particular localities. A study of the connections between landscape and people should dwell on the taskscape for insight into how agricultural landscapes grew and changed over time.

Acknowledgments. This research would not have been possible without the assistance of many people and institutions in Bolivia and the United States. In $\mathbf{L a ~ P a z}$, the Instituto Nacional de Arqueología de Bolivia, and Arq. Javier Escalante, its director, were particularly gracious and helpful. Ing. Freddy Arce assisted with administrative matters. In Trinidad, thanks go to Oscar Saavedra, Arnaldo Lijerón, Rodolfo Pinto Parada, Ricardo Bottega, Celia and Teresa Pérez Chávez, the Universidad Autónoma del Beni, the Prefecture of the Beni, the Museo Etnoarqueológico "Kenneth Lee," and the Fundación Kenneth Lee. In Santa Ana, heartfelt thanks to Jaime and Georgina Bocchietti, the Museo Regional de Arqueología Yacuma, the Alcalde and 
the Sub-Prefecto, and the Sub-Central de Pueblos Indígenas Movima. Without the goodwill and cooperation of all of these friends and institutions, this research would not have been possible.

Fieldwork was carried out through the AgroArchaeological Project of the Beni, and I thank Clark Erickson, its director, for his ongoing collaboration and support. Thanks are due to Chris Gilhooley, who helped digitize the Iruyañez earthworks. An early version of this paper was presented at the 2006 SAA meetings in San Juan, in a session chaired by Jason Ur and Verónica Pérez-Rodriguez. Vernon Scarborough, Wendy Ashmore, Greg Borgstede, and Susan Frith each read drafts of the manuscript and offered many useful comments, which have improved it substantially. Will Crampton helped with the identification of fish. Claudia Rivera translated the abstract. Finally, the hard work and insight of three anonymous reviewers are gratefully appreciated. The flaws that remain are the result of failing to follow their sound advice.

\section{References Cited}

Anschuetz, Kurt F., Richard H. Wilshusen, and Cherie L. Scheick 2001 Archaeology of Landscapes: Perspectives and Directions. Journal of Archaeological Research 9(2): 157-211. Arce, Julio

1993 Evaluación y comparación de rendimientos de cuatro cultivos en tres anchuras de camellones (campos elevados) en la Estación Biológica del Beni (Prov. Ballivian, Dpto. Beni). Unpublished Thesis, Department of Agronomy, Universidad Técnica del Beni.

Ashmore, Wendy

2002 Decisions and Dispositions: Socializing Spatial Archaeology. American Anthropologist 104:1172-1183.

Atkinson, Richard J. C.

1961 Neolithic Engineering. Antiquity 35(140):292-299.

Bevan, Bruce W., and Anna C. Roosevelt

2003 Geophysical Exploration of Guajará, a Prehistoric Earth Mound in Brazil. Geoarchaeology Vol 3(2003):287-331.

Blaikie, Piers, and Harold Brookfield (editors)

1987 Political Economy of Soil Erosion in Developing Countries. Methuen, London.

Block, David

1994 Mission Culture on the Upper Amazon. University of Nebraska Press, Lincoln.

Boom, Brian

1986 Ethnobotany of the Chacobo Indians, Beni, Bolivia. Advances in Economic Botany 4. The New York Botanical Garden, New York.

Brookfield, Harold

2001 Exploring Agrodiversity. Columbia University Press, New York.

Chicchon, Avecita

1992 Chimane Resource Use and Market Involvement in the Beni Biosphere Reserve, Bolivia. Ph.D. dissertation, Department of Anthropology, University of Florida, Microfilms, Ann Arbor.

Crevels, Mily, and Hein van der Voort

2008 The Guaporé-Mamoré Region as a Linguistic Area. In From Linguistic Areas to Areal Linguistics, edited by Pieter Muysken, pp. 151-179. John Benjamins Publishing Company, Amsterdam and Philadelphia.
Crumley, Carole

1987 Regional Dynamics: Burgundian Landscapes in Historical Perspective. Academic Press, San Diego, California. 1994 Historical Ecology: Cultural Knowledge and Changing Landscapes. School of American Research Press, Santa Fe, New Mexico.

Denevan, William

1966 Aboriginal Cultural Geography of the Llanos de Mojos. Iberoamericana 48. University of California Press, Berkeley.

1982 Hydraulic Agriculture in the American Tropics: Forms, Measures and Recent Research. In Maya Subsistence: Studies in Memory of Dennis Puleston, edited by Kent Flannery, pp. 181-203. Academic Press, New York.

2001 Cultivated Landscapes of Native Amazonia and the Andes. Oxford Geographical and Environmental Studies. Oxford University Press, Oxford.

Dillehay, Thomas D.

2007 Monuments, Empires, and Resistance: The Araucanian Polity and Ritual Narratives. Cambridge studies in archaeology. Cambridge University Press, New York.

Dillehay, Thomas D., Herbert H. Eling, Jr., and Jack Rossen

2005 Preceramic Irrigation Canals in the Peruvian Andes. Proceedings of the National Academy of Sciences of the United States of America 102(47):17241-17244.

Dillehay, Thomas D., Mario Pino Quivira, Renée Bonzani, Claudia Silva, Johannes Wallner, and Carlos Le Quesne

2007 Cultivated Wetlands and Emerging Complexity in South-Central Chile and Long Distance Effects of Climate Change. Antiquity 81:949-60.

Downing, Theodore E, and McGuire Gibson (editors) 1974 Irrigation's Impact on Society. Anthropological Papers of the University of Arizona No. 25. University of Arizona Press, Tucson.

Drennan, Richard

2008 Chiefdoms of Southwestern Colombia. In Handbook of South American Archaeology, edited by Helaine Silverman and William H. Isbell, pp. 381-404. Springer, New York.

Dunnell, Robert C.

1992 The Notion Site. In Space, Time and Archaeological Landscapes, edited by Jacqueline Rossignol and LuAnn Wandsnider, pp. 21-42. Plenum Press, New York.

Eder, Francis J.

1985 [1791] Breve descripción de las reducciones de Mojos. Translated by Josep M. Barnadas. Historia Boliviana, Cochabamba.

Erasmus, Charles J.

1965 Monument Building: Some Field Experiments. Southwestern Journal of Anthropology 21(4):277-301.

Erickson, Clark L.

1999 Neo-environmental Determinism and Agrarian 'Collapse' in Andean Prehistory. Antiquity 73:634-42.

2000 An Artificial Landscape-scale Fishery in the Bolivian Amazon. Nature 408:190-193.

2006a Intensification, Political Economy, and the Farming Community : In Defense of a bottom-up perspective of the past. In Agricultural Strategies, edited by Joyce Marcus and Charles Stanish, pp. 334-363. Cotsen Institute of Archaeology, Los Angeles.

2006b The Domesticated Landscapes of the Bolivian Amazon. In Time and Complexity in Historical Ecology, edited by Clark Erickson and William Balée, pp. 235-278. Columbia University Press, New York.

2008 Amazonia: The Historical Ecology of a Domesticated Landscape. In Handbook of South American Archaeology, edited by Helaine Silverman and William $H$. Isbell, pp. 157-184. Springer, New York. 
Erickson, Clark L., and William Balée

2006 The Historical Ecology of a Complex Landscape in Bolivia. In Time, Complexity and Historical Ecology, edited by William Balée and Clark L. Erickson, pp. 187-234. Columbia University Press, New York.

Erickson, Clark L., and Kay Candler

1989 Raised Fields and Sustainable Agriculture in the Lake Titicaca Basin. In Fragile Lands of Latin America: Strategies for Sustainable Development, edited by John O. Browder, pp. 230-248. Westview Press, Boulder, Colorado.

Erickson, Clark L., and John H. Walker

2009 Causeways as Landscape Capital. In Landscapes of Movement, edited by James E. Snead, Clark L. Erickson, and J. Andrew Darling, pp. 232-252. University Museum Publications, Philadelphia.

Fernea, Robert A.

1970 Shaykh and Effendi: Changing Patterns of Authority Among the El Shabana of Southern Iraq. Harvard University Press, Cambridge, Massachusetts.

Golson, Jack and Axel Steensburg

1985 The Tools of Agricultural Intensification in the New Guinea Highlands. In Prehistoric Intensive Agriculture in the Tropics, edited by lan Farrington, pp. 347-384. BAR International Series 232. British Archaeological Reports, Oxford.

Hanagarth, Werner

1993 Acerca de la geoecología de las sabanas del Beni en el noroeste de Bolivia. Instituto de Ecología, La Paz.

Heckenberger, Michael J., J. Christian Russell, Carlos Fausto, Joshua R. Toney, Morgan J. Schmidt, Edithe Pereira, Bruna Franchetto, and Afukaka Kuikuro

2008 Precolumbian Urbanism, Anthropogenic Landscapes, and the Future of the Amazon. Science 321 (5893): 1214-1217.

Holmberg, Allan R.

1950 Nomads of the Long Bow: The Siriono of Eastern Bolvia. Publication No. 10. Smithsonian Institute of Social Anthropology, Washington DC.

Ingold, Tim

1993 The Temporality of the Landscape. World Archaeology $25(2): 152-174$.

Janusek, John, and Alan Kolata

2004 Top-down or Bottom-up: Rural Settlement and Raised Field Agriculture in the Lake Titicaca Basin, Bolivia. Journal of Anthropological Archaeology 23:404-30.

Keller, Franz

1874 The Amazon and Madeira Rivers: Sketches and Descriptions from the Note-book of an Explorer. D. Appleton and Co., New York.

Kolata, Alan

1986 The Agricultural Foundations of the Tiwanaku State: A View from the Heartland. American Antiquity 51:748-762.

Kolata, Alan, and Charles Ortloff

1996 Agroecological Perspectives on the Decline of the Tiwanaku State. In Tiwanaku and its Hinterland, Vol, 1, edited by A. Kolata, pp. 181-201. Smithsonian, Washington, DC.

Kolata, Alan, Oswaldo Rivera, Juan Carlos Ramirez, and Evelyn Gemio

1996 Rehabilitating Raised-field Agriculture in the Southern Lake Titicaca Basin of Bolivia: Theory, Practice and Results. In Tiwanaku and its Hinterlands: Archaeology and Paleoecology of an Andean Civilization 1, Agroecology, edited by Alan Kolata, pp. 203-230. Smithsonian Institution Press, Washington D.C.

Kolata, Alan, Michael Binford, Mark Brenner, John Janusek, and Charles Ortloff

2000 Environmental Thresholds and the Empirical Reality of State Collapse: A Response to Erickson (1999). Antiquity $74(284): 424-426$.
Kowalewski, Stephen

2008 Regional Settlement Pattern Studies. Journal of Archaeological Research 3(2008):225-285.

Kull, Christian

2009 Landscapes of Fire: Origins, Politics and Questions. In Handbook of Landscape Archaeology, edited by Bruno David and Julian Thomas, pp. 424-430. Left Coast Press, Walnut Creek, California.

Langstroth, Robert

1996 Forest Islands in an Amazonian Savanna of Northeastern Bolivia. Unpublished Ph.D. Dissertation, Department of Geography, University of Wisconsin.

Lathrap, Donald W.

1970 The Upper Amazon. Praeger, New York.

1977 Our Father the Cayman, our Mother the Gourd: Spinden Revisited, or a Unitary Model for the Emergence of Agriculture in the New World. In Origins of Agriculture, edited by Charles Reed, pp. 713-752. Aldine, Chicago.

Lawton, Harry W., Philip J. Wilke, Mary DeDecker, and William M. Mason

1976 Agriculture among the Paiute of Owens Valley. Journal of California Anthropology 3(1):13-50.

Lombardo, Umberto, and Heiko Prümers

2010 Precolumbian Human Occupation Patterns in the Eastern Plains of the Llanos de Moxos, Bolivian Amazonia, Journal of Archaeological Science 37(8):1875-1885.

McEwan, Colin, Christiana Barreto, and Eduardo G. Neves (editors)

2001 Unknown Amazon. British Museum, London.

Neves, Eduardo G.

2008 Ecology, Ceramic Chronology and Distribution, Long-term History, and Political Change in the Amazonian Floodplain. In Handbook of South American Archae. ology, edited by Helaine Silverman and William H. Isbell, pp. 359-380. Springer, New York.

Olwig, Kenneth R.

1996 Recovering the Substantive Nature of Landscape. Annals of the Association of American Geographers 86(4):630-653

Ostrom, Elinor

1990 Governing the Commons: The Evolution of Institutions for Collective Action. Cambridge University Press, New York.

2005 Understanding Institutional Diversity. Princeton University Press, Princeton.

Oyuela-Caycedo, Augusto

2008 Late Pre-Hispanic Chiefdoms of Northern Colombia and the Formation of Anthropogenic Landscapes. In Handbook of South American Archueology, edited by Helaine Silverman and William H. Isbell, pp. 405-428. Springer, New York

Park, Thomas K.

1992 Early Trends Toward Class Stratification: Chaos, Common Property and Flood Recession Agriculture. American Antiquity 91:90-117.

Pauketat, Timothy R.

2007 Chiefdoms and Other Archaeological Delusions. University of Alabama Press, Tuscaloosa.

Perez-Chavez, Celia

1997 Estudios en camellones en la Estación Biológica del Beni. In Memorias del Congreso Internacional Estación Biológica del Beni, pp. 129-136. Academia Nacional de Ciencias de Bolivia, La Paz.

Piland, Richard

1997 La agricultura tradicional T'simane y su relación a la conservación en la Estación Biológica del Beni. In Memorias del Primer Congreso Internacional Estación Biológica del Beni, pp. 116-119. Academia Nacional de Ciencias de Bolivia, La Paz. 
Politis, Gustavo

2008 The Pampas and Campos of South America. In Handbook of South American Archaeology, edited by Helaine Silverman and William H. Isbell, pp. 235-261. Springer, New York.

Prümers, Heiko

2000 Informe de labores: excavaciones arqueológicas en la loma Mendoza (Trinidad), Ira Temporada, 1991. Instituto Alemán de Arqueología, Bonn.

2001 Informe de labores; excavaciones arqueológicas en la loma Mendoza (Trinidad), 2da Temporada, 2000. Instituto Alemán de Arqueología, Bonn.

2002 Informe de labores: excavaciones arqueologicas en la loma Mendoza (Trinidad), 3ra Temporada, 200l. Instituto Alemán de Arqueología, Bonn.

Pyne, Stephen

2001 Fire: A Brief History. University of Washington Press, Seattle.

Sauer, Carl O.

1925 The Morphology of Landscape. University of California Publications in Geography 2(2): 19-54.

Schaan, Denise

2004 The Camutins Chiefdom: Rise and Development of Complex Societies on Marajó Island, Brazilian Amazon. Ph.D. Dissertation, Department of Anthropology, University of Pittsburgh, Microfilms, Ann Arbor.

Schaan, Denise, Marti Pärssinen, Alceu Ranzi, and Jacó C. Piccoli 2007 Geoglifos da Amazônia ocidental: evidência de complexidade social entre povos da terra firme. Revista de Arqueología 20:67-82.

Scott, James C.

1998 Seeing Like a State. Yale University Press, New Haven. Smith, Adam T.

2003 The Political Landscape: Constellations of Authority in Early Complex Polities. University of California Press, Berkeley.

Stahl, Ann B.

1993 Concepts of Time and Approaches to Analogical Reasoning in Historical Perspective. American Antiquity $58(2): 235-260$

Stearman, Allyn M.

1987 No Longer Nomads: The Sirionó Revisited. Hamilton Press, Lanham, Maryland.

1991 Making a Living in the Tropical Forest: Yuquí Foragers in the Bolivian Amazon. Human Ecology 19:245-260.

Steward, Julian

1930 Irrigation without Agriculture. Papers of the Michigan Academy of Sciences, Arts and Letters 12:149-156.

1933 Ethnography of the Owens Valley Paiute. University of Califorrnia Publications in American Archaeology and Ethnology 3:233-350.

1946 Handhook of South American Indians 7 vols. U.S. Government Printing Office, Washington, DC.

Steward, Julian, and Louis C. Faron

1959 Native Peoples of South America. McGraw-Hill, New York.

Stone, Glenn D.

1991 Agricultural Territories in a Dispersed Settlement System. Current Anthropology 32:343-353.

1993 Agricultural Abandonment: A Comparative Study in Historical Ecology. In Abandonment of Settlements and Regions: Ethnoarchaeological and Archaeological Approaches, edited by Catherine M. Cameron and Steve A. Tomka, pp. 74-81. Cambridge University Press, Cambridge.

1994 Agricultural Intensification and Perimetrics: Ethnoarchaeological Evidence from Nigeria. Current Anthropology 35:317-324.
1996 Settlement Ecology: The Social and Spatial Organization of Kofyar Agriculture. Arizona Studies in Human Ecology. University of Arizona Press, Tucson.

Stone, Glenn D., and Christian E. Downum

1999 Non-Boserupian Ecology and Agricultural Risk: Ethnic Politics and Land Control in the Arid Southwest. American Anthropologist 101(1):113-228.

Townsend, Wendy

1995 Living on the Edge: Sirionó Hunting and Fishing in Lowland Bolivia, Ph.D. dissertation, Department of Anthropology, University of Florida. University Microfilms, Ann Arbor.

Trigger, Bruce

2003 Understanding Early Civlization. Cambridge University Press, New York.

Trombold, Charles D. (editor)

1991 Ancient Road Networks and Settlement Hierarchies in the New World. Cambridge University Press, New York. Versteeg, Aad H.

2008 Barrancoid and Arauquinoid Mound Builders in Coastal Suriname. In Handbook of South American Archaeology, edited by Helaine Silverman and William H. Isbell, pp. 303-318. Springer, New York.

Walker, John H.

1999 Agricultural Change in the Bolivian Amazon, Ph.D. dissertation, Department of Anthropology, University of Pennsylvania, Philadelphia. University Microfilms, Ann Arbor:

2000 Raised Field Abandonment in the Upper Amazon. Culture and Agriculture 22(2):27-31.

2001 Work Parties and Raised Field Groups in the Bolivian Amazon. Expedition 43(3):9-18.

2004 Agricultural change in the Bolivian Amazon/Cambio agrícola en la Amazonia boliviana. University of Pittsburgh Memoirs in Latin American Archaeology, Number 13. University of Pittsburgh, Department of Anthropology, Pittsburgh.

2008 The Llanos de Mojos. In Handbook of South American Archaeology, edited by Helaine Silverman and William H. Isbell, pp. 927-940. Springer, New York.

2011 Ceramic Assemblages and Landscape in the First Millennium Llanos de Mojos, Beni, Bolivia, Journal of Field Archaeology 36(2):119-131.

2012 Regional Associations and a Ceramic Assemblage from the $14^{\text {th }}$ Century Llanos de Mojos. Andean Past 10 , in press.

Wilkinson, Tony J.

2003 Archaeological Landscapes of the Near East. University of Arizona Press, Tuscon.

Wittfogel, Karl

1957 Oriental Despotism: A Comparative Study of Total Power. Yale University Press, New Haven.

Wylie, Alison

1992 Analogy by Any Other Name is Just as Analogical: A Commentary on the Gould-Watson dialogue. Journal of Anthropological Archaeology 1(4):382-401.

Yoffee, Norman

2005 The Myth of the Archaic State. Cambridge University Press, New York.

Zapata, Agustín

1906 [1693] Carta del Padre Agustín Zapata al Padre Joseph Buendía, en la que da noticias del Paititi. In Juicio de límites entre el Perú y Bolivia, edited by Victor Manuel Maurtua, pp. 24-28. Imprenta de Henrich y Compañía, Barcelona.

Submitted November 5, 2009; Accepted December 16,

2010; Revised June 16, 2011. 


\section{The University Press of Colorado}

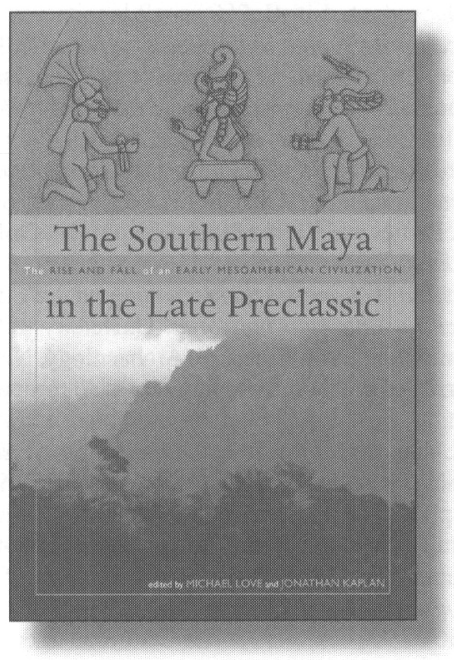

\section{The Southern Maya in the Late Preclassic The Rise and Fall of an Early Mesoamerican \\ Civilization \\ By Michael Love and Jonathan Kaplan}

From $400 B C$ to $A D 250$, the southern Maya region was one of the most remarkable civilizations of the ancient Americas. Filled with great cities linked by flourishing long-distance trade, shared elite ideologies, and a vibrant material culture, this region was pivotal not only for the Maya but for Mesoamerica as a whole. Although it has been of great interest to scholars, gaps in the knowledge have led to debate on the most vital questions about the southern region. Recent research has provided a wealth of broadly based new data that have expanded the understanding of this region and its influence on greater Mesoamerica.

Founded in 1965, the University Press of Colorado is a cooperative publishing enterprise supported, in part, by Adams State College. Colorado State University, Fort Lewis College, Metropolitan State College of Denver, Regis University, University of Colorado, University of Northern Colorado. \& Western State College of Colorado. 